\title{
Anthrovision
}

Vaneasa Online Journal

$6.1 \mid 2018$

Film in Ethnographic Exhibitions

\section{Expanded Footage}

Blending Video into a Colonial Heritage Exhibition

Janine Prins

\section{CpenEdition}

Journals

Electronic version

URL: http://journals.openedition.org/anthrovision/3048

DOI: 10.4000/anthrovision.3048

ISSN: 2198-6754

Publisher

VANEASA - Visual Anthropology Network of European Association of Social Anthropologists

\section{Electronic reference}

Janine Prins, «Expanded Footage », Anthrovision [Online], 6.1 | 2018, Online since 30 June 2018,

connection on 28 July 2019. URL : http://journals.openedition.org/anthrovision/3048; DOI : 10.4000/ anthrovision. 3048

This text was automatically generated on 28 July 2019

(c) Anthrovision 


\title{
Expanded Footage
}

\author{
Blending Video into a Colonial Heritage Exhibition
}

\author{
Janine Prins
}

\section{Thinking Through Heritage}

1 Over the past decade I have been directing my professional camera-curiosity as a visual anthropologist towards the Indo-European side of my family, living witnesses from colonial times and experienced migrators. Since I am entangled in this heritage myself, autoethnography would have been an obvious choice. However, I opted for a more openended approach in order to allow space for contradiction, friction and inconsistencies even when exploring just one, elitist, perspective. Choices made during the development of this personal project - Legacy of Silence - will be discussed here, as well as some first visitor responses, in order to determine how well the strategy of embedding video in a set-up that included material culture objects worked.

2 Ethnographic museum approaches were what first sprung to mind when I decided to make my personal heritage public, since I had been involved with the National Museum of World Cultures in the Netherlands as part of my work (Internet Source 1) on RICHES (Renewal, Innovation and Change: Heritage and European Society, Internet Source 2). Also involved in this European-wide research project were Dutch students of Moroccan descent, who I had met previously when they were trying to find out more about their cultural backgrounds. To this end, they visited the small private Museum Tiskiwin (Internet Source 3) in Marrakech, where Bert Flint had dedicated his life to collecting the material culture of Amazigh populations (indigenous non-Arabic speaking populations of North Africa often referred to as 'Berber'). In this museum the students were allowed direct hands-on access to the collection, without having to overcome layers of bureaucracy and having to put on gloves. Some of the items on display could also be touched, which was demonstrated by a visitor who showed her daughters how she used to cook before migrating to the Netherlands. 
Touching ancestral artefacts in Museum Tiskiwin, Marrakech.

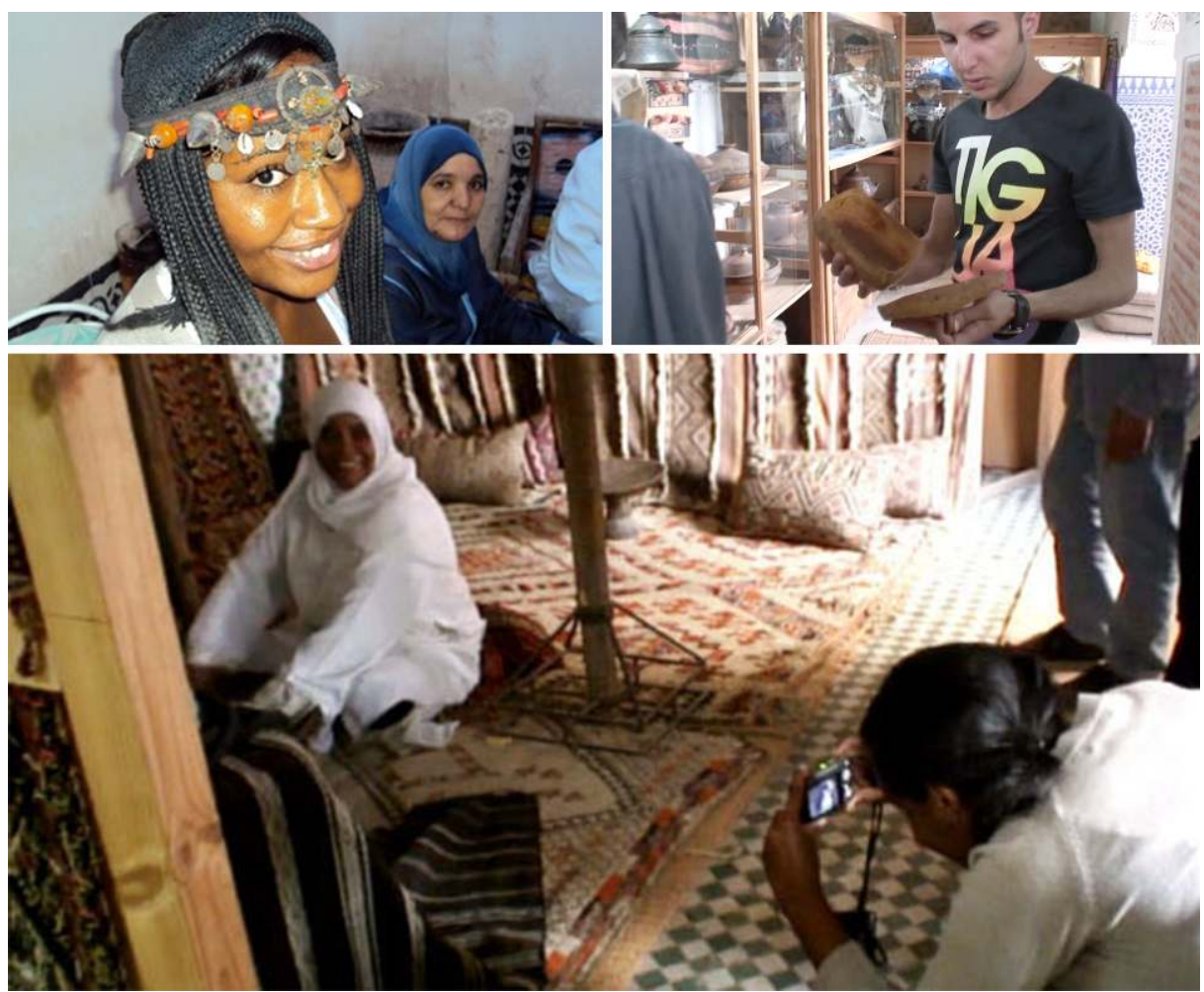

Upper left: photo by Saida si Amer, upper right: video still by Janine Prins, below: video still by Janine Prins.

3 It made me wonder (Internet Source 4) if ethnographic museums closer to home could play a bigger role in helping contemporary citizens to understand their personal trajectories through the objects and lifestyles their ancestors had left behind. However, the young adults involved in the RICHES project ${ }^{1}$ encountered difficulties that made me cautious about museum conventions. What struck me most were their critical remarks regarding the way in which, according to them, public ethnographic museums prevented credible and experiential knowledge, while at the same time heightening exoticism and distance. They did this by, among other things, using sound and image as beautifying décor, placing objects on pedestals behind glass, and creating master narratives that lacked multiple perspectives. In addition to which, food and contemporary culture such as fashion and music were absent, despite the fact that such living heritage played an important role in the digital lives of these young adults brought up in a world of blurry borders, convergence and dynamic reappropriation. They simply did not recognize their own lives, the here and now, in these museums. Moreover, any research into their own backgrounds could be done online; museums did not really provide any added value. Facilitated by Waag Society (Internet source 5), a variety of interesting suggestions were put forward by way of a co-creative process (Internet Source 6) which aimed to bridge the perceived gap between people and institutions. 
Exploration on location: National Museum of Ethnology Leiden.

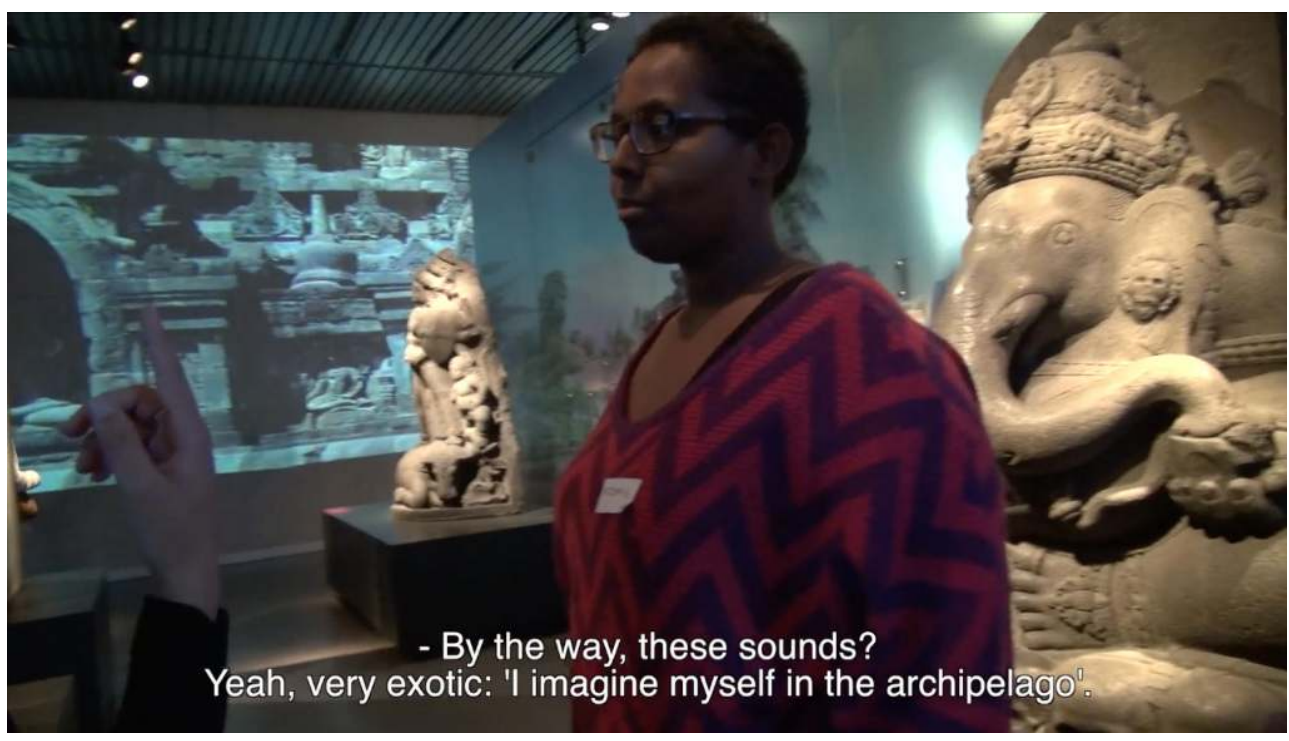

Still from Thinking by Doing (Internet Source 6).

Produced by Waag Society for RICHES.

Various research results were fed into my own project: this generation's performative and dynamic attitude to heritage made the distinction between material and immaterial heritage irrelevant from the emic perspective; being allowed to touch real objects did add value; food and other connections to contemporary life needed to be included; and room for multiple interpretations had to be provided, as well as the freedom to create combinations oneself. Somehow I needed a more playful environment than regular ethnographic museums provide. My thinking went in the direction of installations, a new challenge, for which I sought inspiration from the Belgian SoundImageCulture (SIC) collective (Internet Source 7), ultimately resulting in a first experimental exhibition of Legacy of Silence in February 2017 in Brussels.

5 The formal choices behind the exhibit were strongly influenced by Jacques Rancière's thoughts on emancipated spectatorship (2008), which SIC-coach Pieter Van Bogaert had suggested I take on board, no doubt in an attempt to steer me away from any remaining inclination towards top-down, didactic approaches. To help me rely on the agency of objects, Latour's reflections ${ }^{2}$ from the exhibition Making Things Public (2005) also proved useful, to begin with for the fact that objects could - and should - speak for themselves; the very reason I was venturing outside my cinematic comfort zone. Rancière felt much harder to internalise; I had to learn how to engage visitor agency in new ways. Instead of providing information, or being the author of any narrative, I had to master the skill of triggering interest by presenting open forms. Such open-endedness allows visitors to find their own route to meaning, demands a shifting of positions all the time - now in physical space instead of a sequential timeline - continuously testing the matter-of-factness of perception. Nothing is what it seems at first.

6 To create this open-ended, active attitude that would keep people on their toes, I wanted to break away from museum or art gallery conventions in order to subvert expectations about behavioural conduct. In addition to which, the use of filmic and other materials that might allow predictable juxtapositions in their montage in space needed to be 
avoided, again so as to encourage a move away from fixed positions. And for my naturalistically shot footage not to be taken at face value alone, it too needed an innovative but meaningful embedding in a space, playing an equal role with the other heritage materials in my collection.

\section{Behind the Colonial Décor}

7 It was a strange moment when serious work on Legacy of Silence could finally begin. The project was initially meant to become an essay film, tracing back my family history to colonial times in the Dutch East Indies - now Indonesia. However, my aunt, the main protagonist, died unexpectedly, leaving behind a three story house in Amsterdam full of memories, Asian chinaware, art, furniture, and letters from the colony dating back to 1899. The place had become a mausoleum, could my research footage restore life to this quiet décor?

\section{Aunt Trudy in her house.}

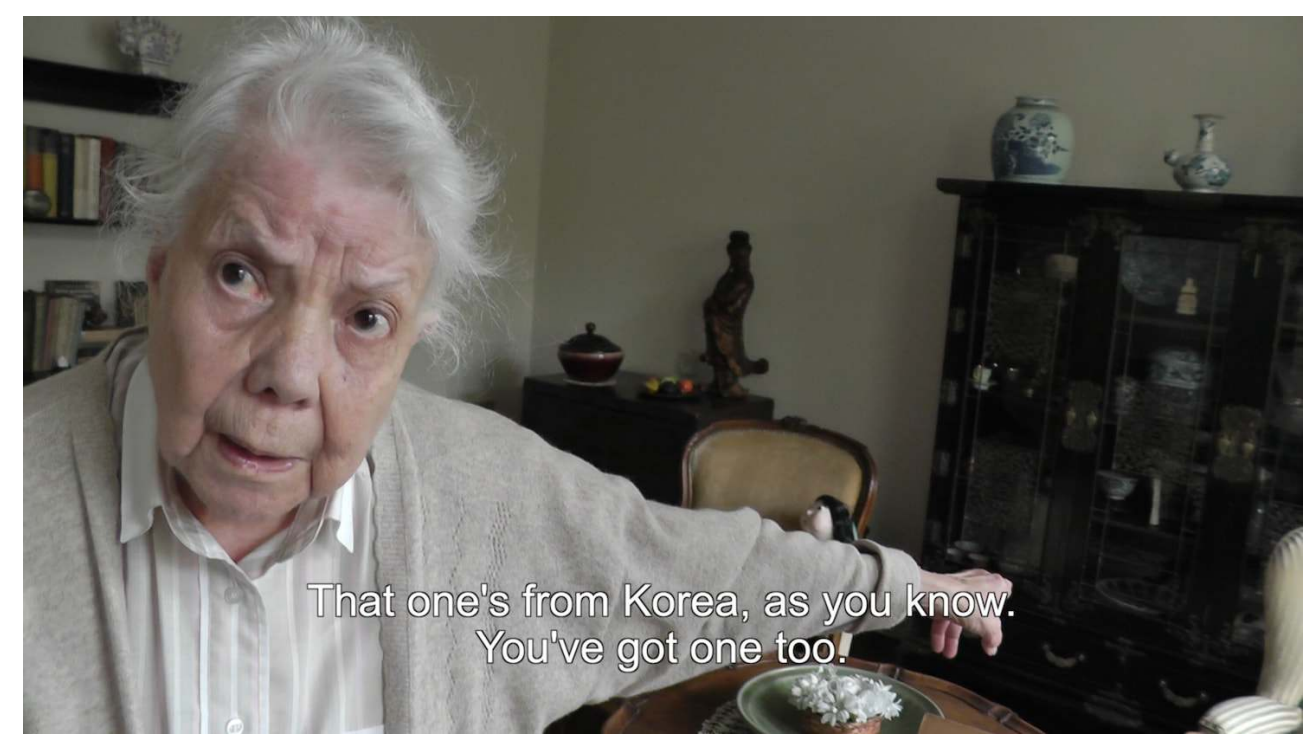

Video still by Janine Prins.

This media file cannot be displayed. Please refer to the online document http:// journals.openedition.org/anthrovision/3048

Video link: https://vimeo.com/219399801 (accessed 13 February 2018).

9 The video footage was gathered over a period of nine years, during which time I had been casually filming my Eurasian relatives born in the Dutch East Indies. Using small amateur cameras, I approached them in an informal manner, recording in a home-movie style, to see what topics would surface, and which people came across well audiovisually. My aunt Trudy turned out to have the best memory and performance of them all. Even so, she was camera shy and not at all happy for me to scratch at the surface of carefully suppressed war memories and painful migration experiences. Over the years she gradually opened up, allowing glimpses into the silenced parts of her life. The struggle to overcome the reluctance to remember can be clearly seen in the video material through the priceless 
facial expressions and gestures in response to my annoying perseverance. This meant I needed to maintain the synchronous integrity of sound and image intact. Furthermore, each separate conversation showed a different mood that was telling in itself, provided it was allowed screen time. Although unfinished, the existing video recordings could suit an oral history project.

The safest way into my aunt's past life in the Dutch East Indies was to ask her about the objects in her house, many of which she treated like museum pieces, representing prewar memories from a time when her mother - my grandmother - had had a flourishing career as a criminal lawyer in the multicultural harbour city of Surabaya on Java, despite the fact that she was of mixed race. Race, class and gender all played important roles in the history that my family were part of. For two generations, male forefathers had migrated to countries under Dutch colonial rule to better their lives overseas, marrying women locally. During the three-and-a-half-year Japanese occupation, most of my relatives ended up in concentration camps. The ensuing struggle for independence lasted four years, ending in 1949. This Indonesian National Revolution involved bloody armed conflict, the messy beginnings of which occurred in Surabaya, where freedom fighters fought allied forces with bamboo spears, and my relatives tried to survive the battles. Life in Japanese concentration camps was considered peaceful in comparison to struggling to survive inside this front-line war zone.

By 1961, the last of my relatives had left Indonesia, expelled for not being dark-skinned and Asian enough, though not before they had arranged for fragile chinaware and hardwood chests to be sent out, across oceans, to Europe, where my relatives were considered too dark-skinned and Asian to be allowed to belong. For these people of mixed race, the somewhat derogatory term INDO - short for Indo European - was coined. Today this same group proudly refers to itself as 'In Nederland Door Omstandigheden' (in the Netherlands due to circumstances).

12 In the rather hostile and (literally) cold climate of the Netherlands in the immediate aftermath of World War II, my professionally educated relatives decided to shut themselves up inside their new houses and participate as little as possible in the outside world, or else they chose to migrate to friendlier shores, such as Canada. Their homes became safe havens, decorated with memories of a lost lifestyle, where they need not feel the fall from favoured elite to outcast minority.

13 The next generation grew up surrounded by well-travelled Asian items and furniture that we were not allowed to touch either physically or verbally. As a child I complied, but now as a middle-aged niece (my own parents are no longer alive) I decided to put questions to the last surviving family members about the décor in which we were brought up, which they treated as reified colonial heritage. The fact that I was not interested in embalming the past, in heritage as something to be preserved, but rather as a contentious legacy to be dealt with, I often had to keep my thoughts to myself.

14 Asking questions is one thing; having to live with the answers turned out to be a challenge at times. Memories of having been caught up in a fully-fledged guerrilla war as teenage girls after suffering more than three years of malnutrition and witnessing torture in concentration camps of course stirred up emotions of empathy. But the views on race and class that I encountered were harder to swallow. Still, it was not my role to judge; complex situations such as these, in which perpetrators and victims can be difficult to tell apart, are never black and white. My project was conceived as an inquiry into 
colonial times and mindsets within my own family, in order to shed light on the here and now. For instance, what made my grandparents feel that they could turn a blind eye to the independence movement? What made them think that the Japanese would be incapable of occupying the Indonesian archipelago? What is it that fuel tensions more generally, what makes people deaf and blind to injustice? What sort of inequality is taken for granted in daily life, then and now? Was the nursing maid in my great-grandfather's photo album the only one without a name? In other words: what led to inclusion and exclusion at that time? Clearly, the micro world of my family connects to the bigger picture. The question was how best to bring that to the fore through a collection of all available materials: video scenes, objects, documents, photographs, diaries, furniture and foods.

Eurasian ancestors in the family records.

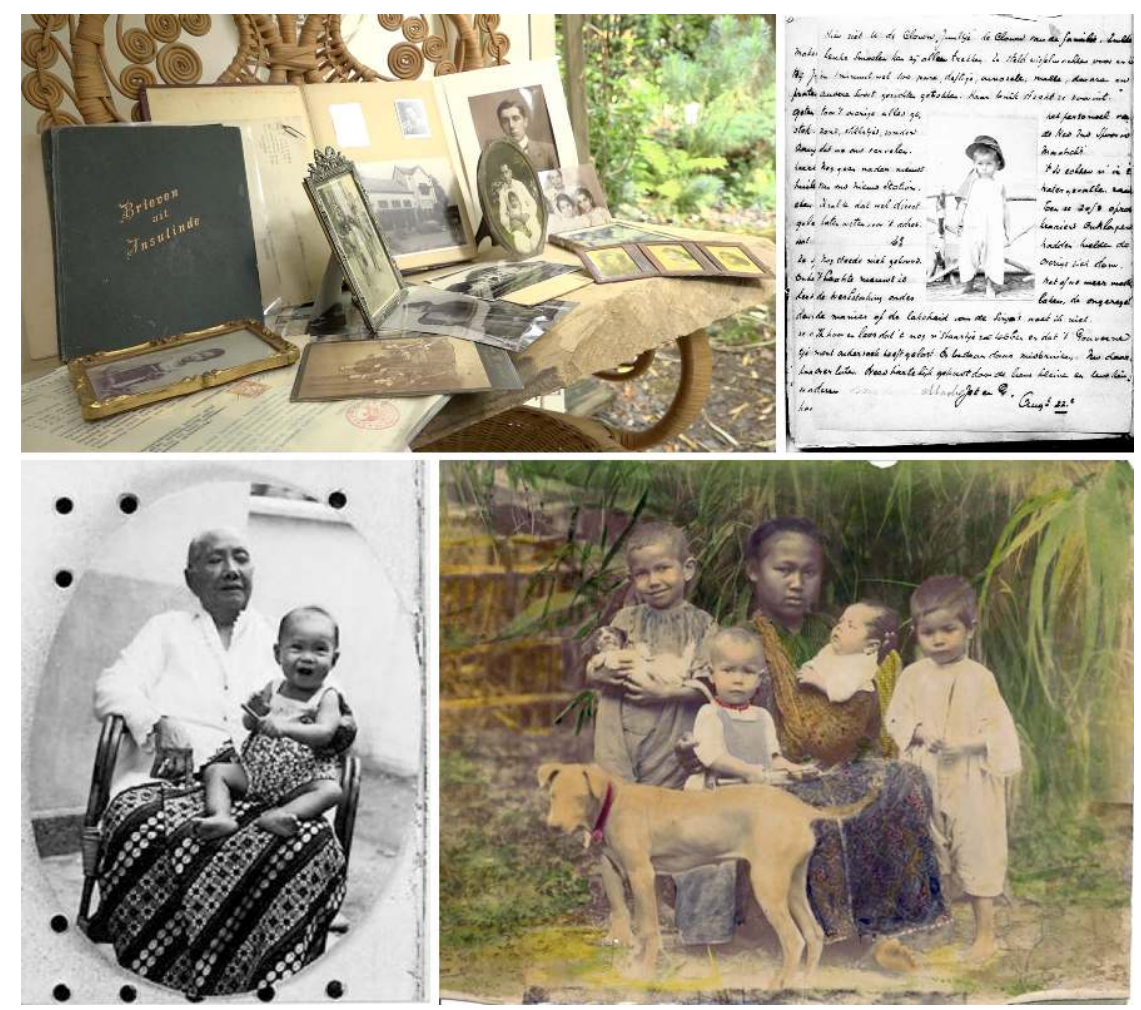

Top left: photo Janine Prins, top right: letter by Gerrit Adolfs 1899, below: two photos by Gerrit Adolfs

\section{A Living Space}

As an independent collection owner, curator and artist all in one, unburdened by institutional responsibilities towards this (however disorganised) 'archive', I happily discarded the idea of framing objects behind glass due to their perceived precariousness or fragility. Visitors would find authentic materials that they could hold, move around, use, and smell, which I hoped made for a pleasant surprise. It was withholding contextual information, a master narrative or scenography, however, that felt a more daring strategy in the context of conventional practices. How would 'emancipated' visitors deal with that, in an overwhelmingly rich presentation that included more than ten video loops of different lengths and screen sizes, text to read, things to eat and drink, and 
various objects here and there? And what would they make of the leafy bamboo in the room and its sound coming from above?

In order to bring it all together, an additional video Introduction to 'Legacy of Silence' was made that presented my subjective voice cinematographically, and which included a monologue intérieur that reveals my own involvement and entanglement in the entire history. Here, I was no distant observer, but an equal-footed 'other' myself, equally affected and involved in this history as the relatives I had filmed. This particular video was placed on the largest screen near the entrance to serve as an introduction. As it turned out, however, most visitors chose to look at this contribution last. It seems that they wanted to glue everything together themselves first, or simply got sucked into the sphere of privacy that had been created deeper in the space.

\section{Visitors at Legacy of Silence.}

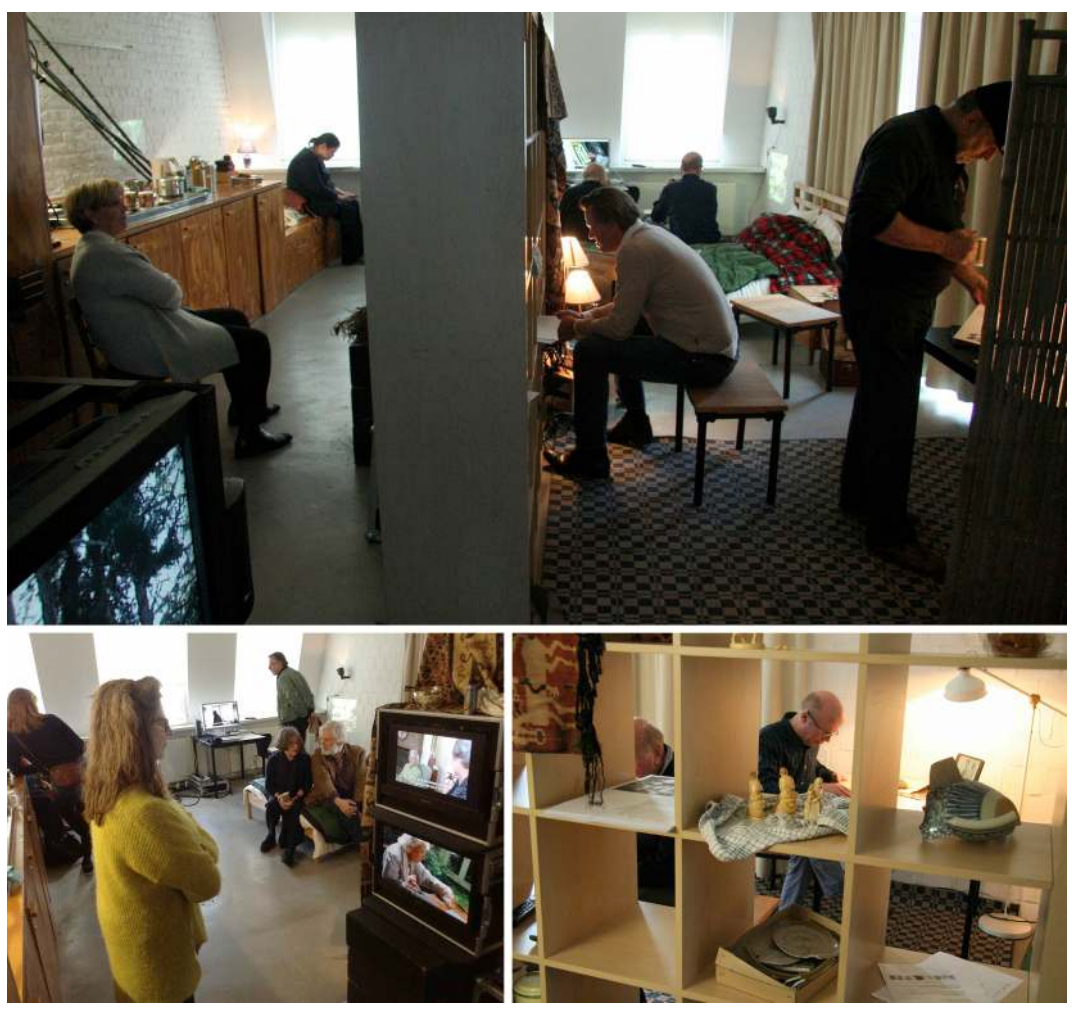

Photos by Janine Prins.

This media file cannot be displayed. Please refer to the online document http:// journals.openedition.org/anthrovision/3048

Video link: https://vimeo.com/224075377 (accessed 2 February 2018).

The exhibit was put on display inside a studio apartment on the sixth floor of the Beursschouwburg (Internet Source 8) building in Brussels, which allowed for an immersive atmosphere similar to that of a private home. The bare studio was used as a set that needed very little additional decoration to create a context of privacy and give a sense that this was still a work in progress. Meanwhile, downstairs in the venue of the Beursschouwburg my fellow participants of the SIC year 2016 showed their work, which was either completed or, like mine, in progress, having spent a year of mutual cross- 
pollination across artistic and scientific disciplines. Their films, accompanied by performances in some cases, were shown in the main theatre, and the only other installation including sound and images was positioned in the hallway next to the elevator leading to my temporary studio space upstairs. All these presentations were promoted within the networks of SIC, Beursschouwburg and the exhibiting artists. Films and performances were shown once, the installations could be visited at fixed times on 23-25 February. A total of 55 people made their way up to my installation with an average stay of 1.5 hours - quite long, yet understandable, since 35 of them had travelled half a day from the Netherlands. In order to make it worth their while, I had offered 20 personal relations lunch nearby, prior to the opening of the exhibition. Among the people I invited were quite a few visual anthropology graduates whom I had supervised in the past. In other words: the majority of visitors either had a personal or a professional relationship with me, the material on display, the Beursschouwburg programming or the larger SIC network; not exactly a so-called general audience, but for the query at hand that did not matter to me.

Once arrived upstairs, visitors would encounter a pop-up work and living space inhabited by myself as artist-in-residence. I would be present, making coffee and tea (sourced from Indonesia), serving biscuits (Dutch speculaas, with an aroma of spices that have been imported since colonial times) and cooking white rice - another homely smell belonging to a minority in an environment where potatoes are the traditional staple food.

When entering Legacy of Silence, anything but silence meets the ear, as all videos are played at a volume at which you can just hear the spoken word. The space is filled with audiovisual anecdotes and memories, most framed in small picture frames so as to resemble moving snapshots, all placed inside an apartment decorated in Eurasian style. The videos vary in length between 30 seconds and 15 minutes, with some projected onto the walls, others running on small DVD players, one on a regular television, two on larger screens with additional speakers and two stacked on top of each other in crates.

Added to the overall human cacophony is a sound layer of bamboo being cut. Coffee or tea is provided in mugs bearing an Indonesian inscription or cartoon, which perhaps only a few people will notice. Just as only a few people will notice the small image beamed onto the wall in the kitchen area, a silent short loop depicting a freckled arm polishing silverware.

This media file cannot be displayed. Please refer to the online document http:// journals.openedition.org/anthrovision/3048

Video link: https://vimeo.com/255564844 (accessed 13 February 2018). 
Wall used for projection next to coffee and tea self-service.

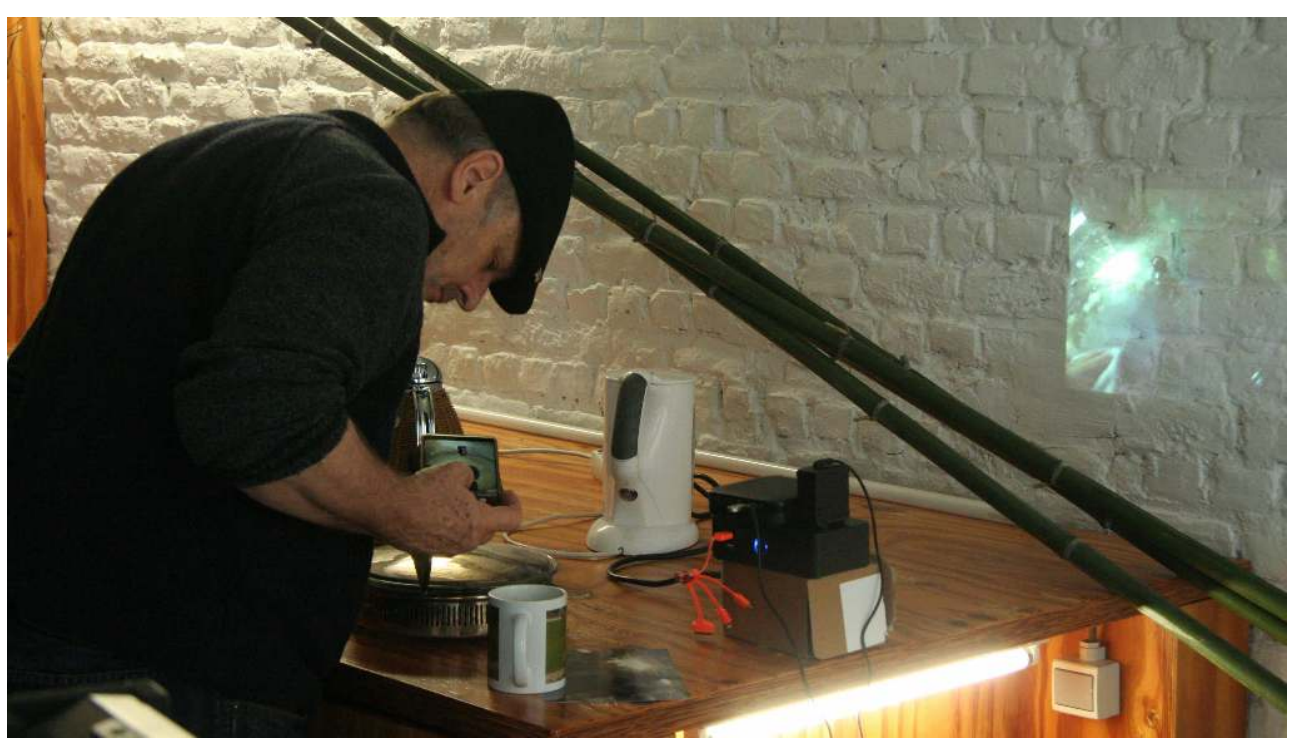

Photo by Janine Prins.

Visitors had to choose their own path and were told they could touch whatever they wanted and should make themselves at home. I took the role of a somewhat absentminded host pouring coffee and tea, and did not respond to any questions or comments inside the exhibition. On their way out, however, I accompanied visitors back down to the ground floor in the elevator - a security requirement that I was able to turn into a research opportunity, as this was where I did elicit responses and took notes in order to find out to what extent the exhibition strategy was a success.

\section{Visitors Made Performers}

One important question was to what extent the right balance had been struck between withholding and providing cues that allowed people to make sense of it all. The following may serve to illustrate the importance of restraint when hoping to produce a desired effect. Visual anthropologist Rosanne van den Berg wondered why the close-up image of skin was projected so that it was so small on the kitchen wall, almost hidden behind the objects in front of it, while it seemed important to the overall exhibition. I temporarily suspended my policy of not responding to any questions or comments as I wanted to share what I had learned during my time in Belgium: "Why force-feed what you find important?" She reflected on this for a moment, then remarked: "Perhaps I'm giving it so much importance precisely because it feels as if I've made a discovery myself?" (my translation).

As for withholding factual information, I had hesitated over whether a family tree or historical timeline should be added, but feared it would have directed visitors to read into specific particularities too much, whereas I aimed for open-ended interpretations that would transcend my particular family history. For those who could deal with feelings of factual insecurity, this seems to have been a good decision, as the reaction of visual anthropologist Brigitte Borm indicates (my translation): 
Personally I believe your choice to be a strong one. A family tree for instance would make it too easy, preventing one from actively searching for pieces of the puzzle. [...]

I appreciated how you managed to make people part of the highly personal and complex experience. For me it became rather difficult to either denounce or have compassion for your family, precisely because you succeeded in showing so many different perspectives, while maintaining integrity and transparency. (Email 24 February 2017.) else was around, recalls that it was the "private atmosphere" created by the arrangement of multiple small screens "like little lamps" that aroused his curiosity and encouraged him to explore, whereas initially he had believed that this amount of video material would never fit into an installation. However, in this enhanced homely setting it made sense, due to the fact that the form and content complemented one another (personal communication, 25 June 2017). In other words, the private atmosphere should remain an essential feature of potential future exhibits. Some even feel invited by the intimacy to include others in their experience. Former art manager Inger van Dongen commented: "Because you start talking to each other, the space itself becomes alive and not museum-like. If there were more space, the experience would become less homely, less intimate" (my translation). Apparently a "nonmuseum-like' experience of an exhibition can invite spontaneous contact between visitors. This might be useful for museums seeking to serve as contact zones (Clifford 1997). In this case, however, there were of course no power distances between me, posing as a member of a source community, and an institution, since I operated independently with full artistic control over form and content. Perhaps museums could invite communities to bring their own (in)tangible objects and create installations themselves, in this way renegotiating differences. Apart from an intimate atmosphere and an informal layout, a lack of explicit information combined with exposure to multiple media displays and direct access to a variety of authentic sources are seemingly essential ingredients to establish communication between strangers, as the response of filmmaker Alex Pitstra illustrates:

I found the lack of information about who's who and what happened when annoying. I needed the presence of other people to make up for my own lack of knowledge. Information enriches the way I look at things; it's just a need that I have. So I'm being challenged to collect bits of information that I need by reading documents and looking for people to talk to; very interactive. On my own, I would have got much less out of it. Now [I] also received context from other people, which made [the work] feel like a new entity. To me, those people have become part of the work. (personal communication 23 February 2017, my translation.) 
Communication between strangers at Legacy of Silence.
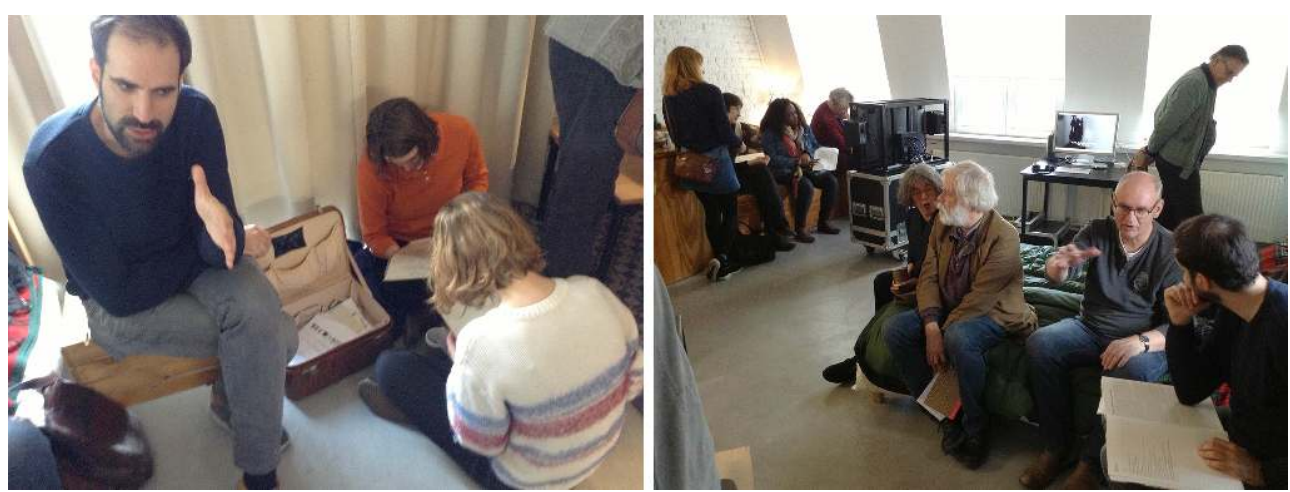

Photos by Janine Prins.

Alex Pitstra continues, explaining how he turned his visit into an exploration, using multiple sources to construct his interpretation. Half hidden inside a closed crocodile leather suitcase in a small corner, he found documents:

Reading a letter that describes how soldiers had looted the house makes history come alive [...] you are transported to a different time and feel conflicting loyalties about the Netherlands ... the loss of status, the denial of 'others'... isn't this still going on in the here and now? It's like a circular movement where each time we insist on keeping up an appearance of superiority, time and again, apparently a deeply engrained arrogance [...] In school, I could never understand why a Moluccan friend of mine would get so worked up. That was basically me denying history. (Personal communication, 23 February 2017.)

The work seemingly manages to mobilise historical consciousness and responsibility in the present, though Alex need not feel personally responsible for the national amnesia about disturbing events in the past that have not permeated through the collective conscious. He dares to acknowledge the excluding 'other' within himself, in his own lifetime.

Not everyone is so reflective and verbally able. When others wondered whether the main protagonist of Legacy of Silence was the author, the family or Dutch society as a whole, I took that as a similar sign that the exhibition strategy had succeeded in its mission to use heritage to encourage reflection on today's world, if not the human condition. It is only coincidence that the era into which I was born is a (post-)colonial one, since Legacy of Silence need not remain limited to a 'decolonisation' discourse; colonialism is only one expression of exclusion, and in general, humanity could reflect more on its pasts in order to reshape its futures.

31 "A past considered 'over' implies an illusion of progress", as Mieke Bal (2013:24) so nicely put it when writing about the politics of video installations. She argues that installations bind viewers to their own interaction with the space, and that the intersection between movement and space creates an openness to difference and doubt. Therefore, one finds ideas not illustrated by, but actualized in, a work; according to Bal, video installations can move us to think beyond ordinary boundaries, resulting in the political power of art as 'open effect, not theme'. Other than this performative characteristic, she stresses the benefits of the simultaneous presence of multiple screens used to create heterogeneity in a spatial set-up where it is impossible to see everything at the same time; it involves the visitor in the here and now. 
For Legacy of Silence, I had added objects and sensorial elements into the equation, such as objects made from silver, porcelain, fabric and leather, a game, photos, documents, diaries, plants, household items and food and drinks. The idea was that all of this was blended together into one overall presentation which gave equal merit to each element in an open-ended structure. Curious as to how moving images, sound, smells and still objects were seen to interplay with one another, I collected observations and reflections on these formal aspects.

Direct access to unique authentic materials.
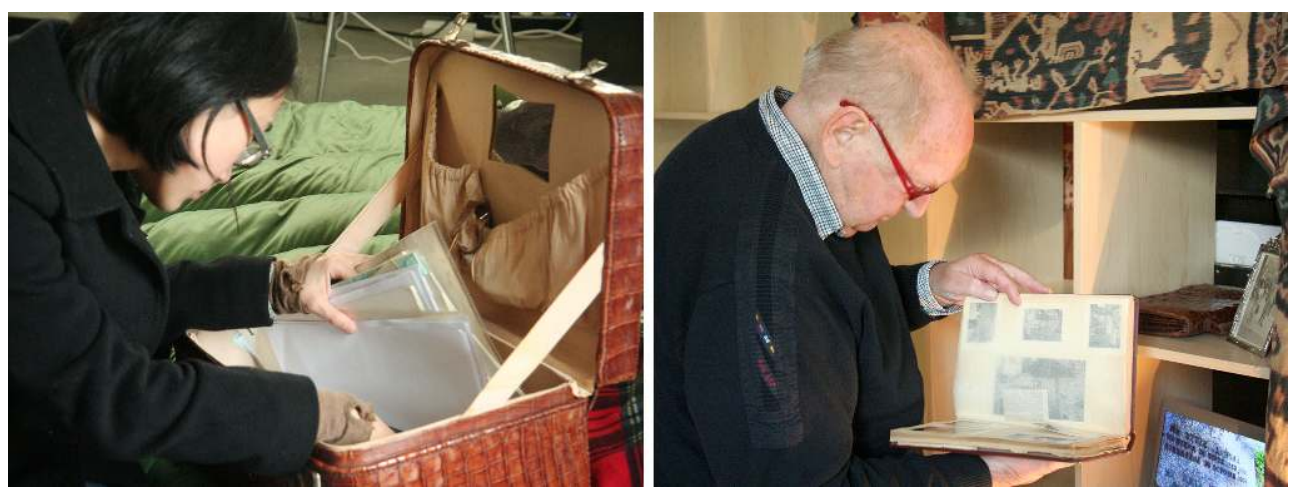

Photos by Janine Prins.

\section{Rhizomatic Crosstalk}

Most visitors went round twice; some would start with the screens, others with the documents and objects, yet all approaches resulted equally in visitors being presented with " $a$ world that gradually reveals itself". Or, as another visitor put it: "A strange, fragmented place, that gradually turns out to be a variety of perspectives on the same history". It appears that when people are willing to invest time and effort, Kuleshov's principle of montage is borne out, even across media and materialities: "The moving images, objects, spoken and written language and the atmospheres all complement each other." Even better, for some, the realisation that there was a connection between different elements provided additional pleasure, and hence involvement: "It is so funny: you see a little knife lying somewhere, not knowing what it's doing there and suddenly it figures in a video! A great 'aha' experience!" For such cross-referencing to work, there must be some detectable underlying 'leitmotiv', in this case my personal involvement with everything on display helped stage visitor subjectivity: "There is a wealth of material and a lot to take in, but it feels as a privilege because you get to look at your personal life and touch original documents."

According to visual anthropologist Ildikó Plájás, neither the objects, nor the screens demanded more attention than the other:

Many stories are hanging in the room: they start on one screen, continue in an object, then are being narrated by the artist herself. There is no single beginning, one dramatic line or an absolving end. They are "rhizomatic" (Deleuze \& Guattari), spread across objects, archival footage and the bodies (artist and visitor's) moving around and engaging with the images and objects - lots of tactility as well, and smell (old albums)! [...] I explicitly remember the story of the Japanese bombing - it travelled across many of the stories, objects and memories. [...] And the visitor gets entangled in these stories, is not looking at them but is in the middle of them, being 
part of it: I'm sitting on the bed leafing through a book. My notebook and pen are put on the table next to other objects which are part of the exhibition. (Email, June 12, 2017.)

This last experience suggests that a created space could benefit from having a physical quality to it, increasing the sense of belonging, adding to the performance. A visitor who feels blended into the surroundings can piece together the various elements of the installation.

visitors mentioned that they experienced the non-linear, open-endedness as crucial because "it helped me to let go of preconceived notions, it is an invitation to surrender yourself to it" (my translation). Others stressed that they had enjoyed being able to follow their own intuition and route, as well as the freedom of thought and to set their own pace, without having to adjust to a preconcerted route or imposed storyline. "You find your own way, create your own montage, apply your own knowledge and responses" (my translation). It has to be said that these remarks came from young adults who have been brought up in a Dutch project-based education system that stimulates self-motivation at the expense of traditional teaching approaches using master narratives. On the whole, the exhibition attracted a biased audience, as most belonged to my own professional and personal networks, and those who had travelled long distances were of course inclined to spend more time and effort in order to make the journey worth their while. Nevertheless, they served me well as subjects on which to test out the effect of the formal and material choices that I had made in the aim of encouraging subjective experiences and reflections.

Other responses affirmed my fear of enhancing or at least confirming existing stereotypes. For instance, visitors who expressed interest in cultural heritage and precious heirlooms in terms of a sadly bygone era interpreted the immersive experience as 'nostalgia for a lost age', to which another visitor retorted: "How can you say that? Surely you could tell that life there wasn't a bed of roses" (my translation). Someone else looked at the ivory statuettes saying: "Beautiful patina, don't you think?" (my translation), whereas I feel haunted by the elephant that was killed to obtain it.

The question remains if there could be display methods that provoke a critical response from all members of the public, or at least create an 'atmosphere of democracy' as Latour and Weibel describe in Making Things Public (2005). This would involve bringing people together around objects - or issues - that offer room for newer, more nuanced and complex views than the ones that prevailed hitherto, undermining so-called 'facts', and questioning existing assumptions. Making Things Public makes the case for neutral arenas that bring people together around issues that divide them. And indeed, Legacy of Silence's (de)colonisation theme is one that, even in 2018, still leads to heated debates in Dutch society. However, the aim of this article is not to delve into the social, philosophical and political meaning of the installation, but rather to present an experiential account of a concrete display method in an attempt to create the best possible platforms for meaningful discussion and reflection. Of course, in no way does this method promote narratives pretending to give 'accurate' representations, because it is precisely such views of 'reality' that need to be called into question. In order to make this happen, expanded cinema and installation politics can be useful to nudge things along. 


\section{Narrating in Space}

39 All visitors, as well as the visual anthropology students whose lecture hall I later scattered with screens and objects during a guest lecture, said that they liked the sense of intimacy, subjective voice and authenticity of the original personal objects - in other words, the pleasure of feeling privileged. This creates the right mood, allowing them to feel comfortable, but could serve equally well as part of a nostalgic exhibit. Withholding information seems to have been a trigger that forced people to move through the space in order to make connections, 'zapping' from one screen, object or document to the next, chasing down clues to make sense of it all. These strategies behind the set-up of Legacy of Silence basically belong to the notion of expanded cinema.

For instance, the traditional screen-to-seating configuration is broken up. In total, 75 minutes are presented in various locations, with videos that need foregrounding screened in a larger format with louder audio, and comfortable - albeit unconventional - seating arrangements such as a bed. That said, nothing is ever set in stone: volumes can be adjusted, screens moved elsewhere. One 12-minute video, which I considered to be a backstory that deserved little attention, had been originally placed at eye level when standing or passing by. However, someone decided to adjust this scenography, moving the screen to a lower position so that it could be viewed while seated on a small bench taken from elsewhere.

Viewing arrangement adapted by a visitor.

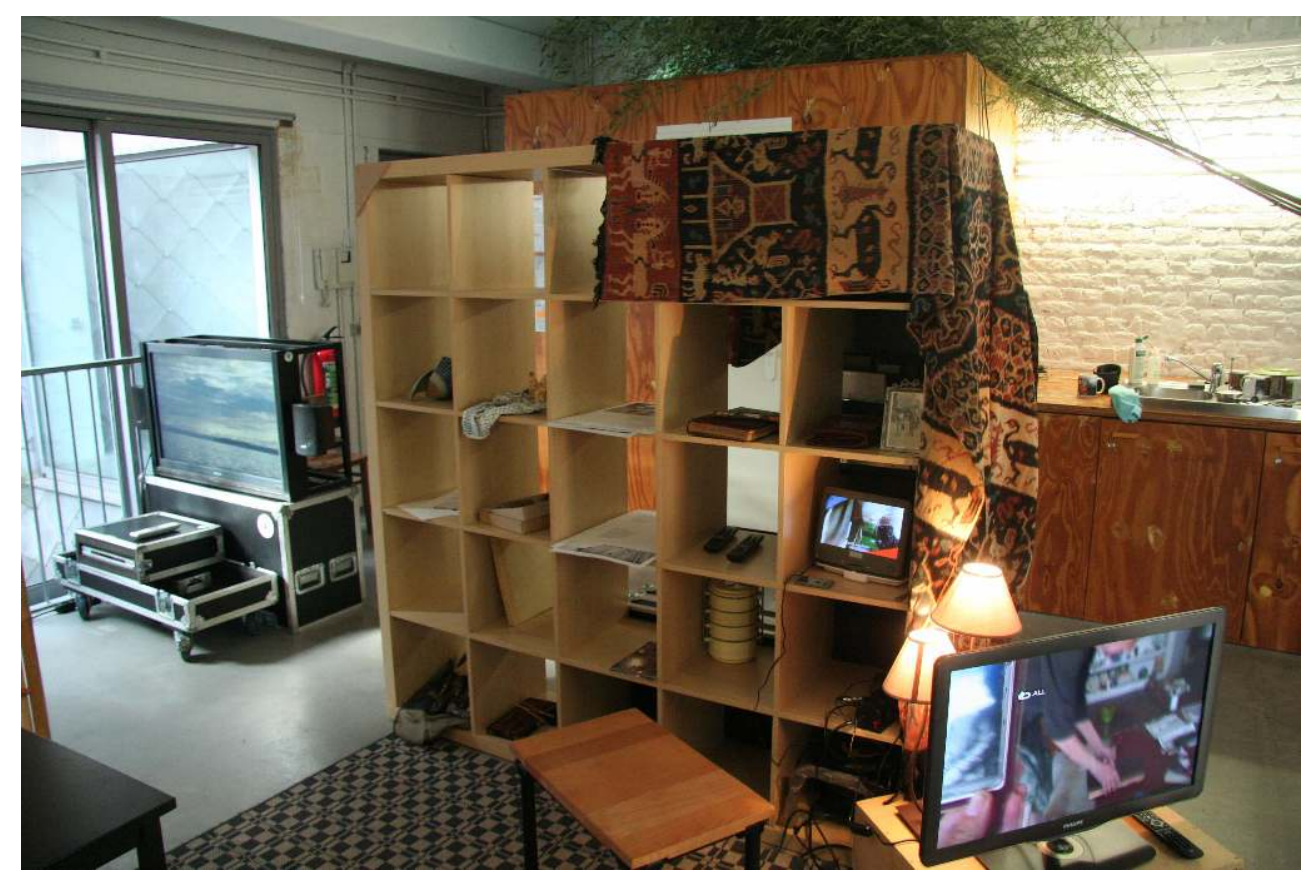

Photo by Janine Prins.

41 Another example of expanded cinema at work involved the small suitcase, initially placed on the floor next to the largest bed. It started travelling through the space, its contents being studied here, then there. This freedom shows "an elevation of the role of visitors to 
that of the performance", which took place due to the creation of "a temporary and physical universe" that allowed for "improvisation and chance" (Elwes 2015: 164-170).

Expanded cinema, and video installations for that matter, both aim to direct attention away from a conventional narrative, through a timespace with coexisting multiple screens, where people are allowed to move around at will. The images move and so do people, in the actual here and now, making meaning themselves, literally shifting position all the time. Narrating in space involves more dialectical moments in far less regulated situations than the traditional cinema screening. What's more, now that we have supposedly entered a post-cinema era in which cinema has been "relocated" (Casetti 2011) into new media and multiple environments, people are moving beyond audiovisual reception towards active bodily sensorial experience. It has been argued that the more personalised and active a visitor's engagement through their bodily senses (using touch, smell, and so on) is, the more involved they become. By disconnecting this art form from its privileged place in cinemas, new viewing conditions and environments can be constructed, and combined with other activities. Watching moving images therefore increasingly involves making choices based on personal interests; it becomes an act or performance by visitors that needs to be masterminded by curators, artists, and visual anthropologists, if so inclined.

Narration through montage in space, or scenography, may be more complex than creating a film meant for projection onto a big screen in the dark, but it has become clear to me that moving image and objects can perfectly complement each other, particularly when applying open-ended expanded cinema practices. These do not lend themselves to linear narratives or top-down didactic approaches as they thrive on allowing room for imagination and multiple perspectives, which is perfectly in line with the notion of heritage as dynamic and performative. This allows for the reshaping of existing fixed narratives and the coexistence of different, sometimes contradictory, perspectives on past and present. In other words: applying expanded cinema practices and installation politics to heritage allows for ethnographic museums to become spaces for reexperiencing the world we live in.

\section{Ways Forward}

First the image started moving, then the visitors, and now so many more elements can be brought together into a multimodal accumulation to create the desired active sensorial experiences. Nowadays, those working with film are no longer forced to lug about $16 \mathrm{~mm}$ film cans, but are the days of travelling light with just a USB stick coming to an end? Then again, how often and where could I repeat Legacy of Silence in the manner described here? Installations and expanded cinema do not travel so easily. A mobile version, with everything shown in, on and around a mini-campervan (plus additional tent), has been envisaged in the aim of presenting the project at other venues, with myself in the role of member of the 'source community'. Bamboo and smaller objects could be brought along, rice could be made on the cooker, and tea and coffee served in the little camper. The only requirements would be fair weather, a lawn and a plug socket - making this a feasible option only a few months a year in Europe. intact, avoiding the kinds of restrictions that visitors to existing institutions are faced 
with: restrictions such as there being no food allowed, no living bamboo, no opportunity to move furniture around, walls and ceilings that are to be left alone, sound can only come through headphones, and so on, and so forth. In addition to logistics, each location will need a different narration approach that matches the specificity of that location, forges another meaning with the same heritage materials. Even more shiftings of positions, and not only by visitors.

Ultimately, the physical experience aspect of Legacy of Silence will be lost once the project settles down, as it will probably move to a website where visitors can select their own routes in some form of digital multimedia space. Creating enough room for imagination in the reductive digital realm will represent yet another challenge. However, the project does have the potential to bring heritage into the public sphere. A QR code, for instance, could be attached to the graves in Indonesia, Canada and the Netherlands of the various characters in this family history, taking anyone interested to a website with online videos or other media about the deceased. Or, RFID chips could be implanted into objects to allow future trajectories across the globe to be followed. What's more, digitising old diaries and photographs provides opportunities to add meaning in the present by creating new forms, adding to the object layer upon layer in new dimensions; creating unforeseen and boundless outcomes.

For each medium there is something lost, something gained. I would say that an all-round experience that does justice to both visitors and heritage items ought to include multiple media and methods combined into a strategy that can be pretty bold. After all, the visitor is already 'emancipated'. Even though my particular audience was strongly biased in this case, my experience with previous film work is that professionals and highly educated viewers had much more difficulty in letting go of preconceptions than the so-called general audience.

But how much room for interpretation will institutions be prepared to allow? Can statefunded institutions truly become spaces for open-ended questioning? Will they dare to broach uncomfortable subjects? Alternatively, we may want to mobilise collections to appear in non-institutionalised contexts altogether. Leaving that aside, my hope is that museums, galleries and other exhibition sites that work with tangible heritage objects will start exhibiting their collections incorporating much more of the sensorial so as to bring them back to life. Let's give things an afterlife in the here and now.

\section{BIBLIOGRAPHY}

\section{Books and articles}

Bal, Mieke. 2013. Thinking in Film: The Politics of Video Installation According to Eija-Liisa Ahtila. London: Bloomsbury.

Casetti, Francesco. 2011. Beyond Subjectivity: The Film Experience. In Subjectivity. Dominique Chateau, ed. Pp. 53-63. Amsterdam: Amsterdam University Press. 
Clifford, James. 1997. Routes: Travel and Translation in the Late Twentieth Century. Cambridge, Massachusetts: Harvard University Press.

Elwes, Catherine. 2015. Installation and the Moving Image. London and New York: Wallflower Press.

Latour, Bruno. 2005. From Realpolitik to Dingpolitik: Or How to Make Things Public. Catalogue text from the exhibition Making Things Public. Karlsruhe: Zentrum für Kunst und Medientechnologie.

Latour, Bruno. 2014. How Better to Register the Agency of Things. Yale: Tanner Lectures. http:// www.bruno-latour.fr/node/588 (accessed 10 December 2018).

Latour, Bruno and Peter Weibel, eds. 2005. Making Things Public: Atmospheres of Democracy. Cambridge, Massachusetts: MIT Press.

Prins, Janine, Hemmo Bruinenberg and Dick van Dijk. 2015. Context of Change for Mediated and Unmediated Heritage. In Transformation, Change and Best Practice for Cultural Heritage processes, http://www.digitalmeetsculture.net/wp-content/uploads/2015/09/RICHES-D4.1-Europeanidentity-belonging-and-the-role-for-digital-CH_public.pdf (accessed 13 February 2018). Pp. 48-77. Online publication.

Rancière, Jacques. 2015 (2008). De geëmancipeerde toeschouwer. Joost Beerten and Walter van der Star, trans. Amsterdam: Octavo.

Films

Prins, Janine. 2017. Introduction to 'Legacy of Silence' video, $8 \mathrm{~min}$. https://vimeo.com/224075377 (accessed in February 2018).

Prins, Janine. 2017. Heritage Items at Home video, 5,5 min. https://vimeo.com/219399801 (accessed in February 2018).

Prins, Janine. 2017. Colonial Self Reflection, loop, 0,5 min. https://vimeo.com/255564844 (accessed in February 2018).

Waag Society: Lotte van Leengoed, Hemmo Bruinenberg, Janine Prins. 2015. Thinking by Doing, video, $21 \mathrm{~min}$. https://co-creation.waag.org/projects/riches-interventions (accessed in February 2018).

\section{Exhibitions}

Bruno Latour and Peter Weibel. Making Things Public: Atmospheres of Democracy, exhibition. Karlsruhe, Germany: Zentrum für Kunst und Medientechnologie, 19 March - 7 August 2005. Janine Prins. Legacy of Silence, mixed media immersive pop-up exhibition. Brussels, 23-25 February 2017; Amsterdam, 2 March 2018; Leiden, 14 June and 15 September 2018.

\section{Internet sources}

Internet Source 1: Prins, Janine. 2015. Designing Dialogues for an Ethnographic Museum (posted on January 27, 2015). On Leiden Anthropology Blog: Media, visual and material culture. http:// www.leidenanthropologyblog.nl/articles/Designing-dialogues-for-an-ethnographic-museum (accessed in December, 2018).

Internet Source 2: RICHES (Renewal, Innovation and Change: Heritage and European Society). http://www.riches-project.eu (accessed in December, 2018).

Internet Source 3: Museum Tiskiwin. http://www.tiskiwin.com (accessed in December, 2018). Internet Source 4: Prins, Janine. 2014. Routes 'En Route': Redesigning Cultural Heritages after Migration (posted on April 28, 2014). On Leiden Anthropology Blog: Media, visual and material culture, 
http://www.leidenanthropologyblog.nl/articles/roots-en-route-redesigning-cultural-heritagesafter-migration (accessed on June 28, 2017).

Internet Source 5: Waag Society: Institute for Art, Science and Technology. http://waag.org/en (accessed on June 30, 2017).

Internet Source 6: Co-creation: Case Studies: RICHES Intervention. https://co-creation.waag.org/ projects/riches-interventions (scroll down for video Thinking by Doing) (accessed December, 2018).

Internet Source 7: SoundImageCulture SIC. http://soundimageculture.org/about?l=en (accessed in December, 2018).

Internet Source 8: Beursschouwburg. http://www.beursschouwburg.be/en/over-ons/ (accessed on June 26,2017$)$.

\section{NOTES}

1. See Prins, Bruinenberg and van Dijk 2015.

2. He reflected in the Tanner Lectures (2014) on the exhibit of 2005.

\section{ABSTRACTS}

Using her own (in)tangible Eurasian heritage objects, the author explores how exhibition practices can be used to complement her video material. Taking its cues from ethnographic museums and expanded cinema, an independent multi-screen experiential exhibit was created, which draws on Jacques Rancière's concept of the emancipated spectator. Visitor responses show that the non-linear open-ended exhibit strategies used to present the media and objects do enhance interest and evoke multiple perspectives. Furthermore, the withholding of factual information invites visitors to engage in a personal quest for connections, sometimes with the help of others. Set in an intimate atmosphere where one is free to follow one's own route, and with direct access to original sources, visitors take on the role of performers inside the work.

En utilisant des objets in(tangible) appartenant à son héritage Eurasien, l'auteure explore comment les pratiques d'exposition peuvent être utilisées pour compléter un matériel vidéo. Prenant appui sur les pratiques d'expositions muséales ethnographiques et sur les stratégies du cinéma élargi, l'auteure à créée une exposition expérimentale multi-écrans s'inscrivant dans le sillage des considérations de Jacques Rancière sur le spectateur émancipé. L'engagement des visiteurs montrent que les stratégies d'exposition non linéaire et ouvertes utilisées pour présenter images, sons et objets suscitent l'intérêt et évoque au spectateur de multiples réflexions. En outre, l'absence d'informations factuelles invite les visiteurs à se livrer à une enquête personnelle, parfois avec l'aide des autres. Se déroulant dans une atmosphère intimiste où l'on est libre de suivre son propre itinéraire, et avec un accès direct à des documents originaux, les visiteurs jouent le rôle d'interprètes autant que de performers au coeur du dispositif d'installation. 
La autora explora, usando sus propios objetos (in)tangibles del acervo cultural euroasiático, cómo las prácticas de exposición pueden ser usadas para complementar su material filmográfico. Tomando pistas de museos etnográficos y del cine expandido, se creó una exposición experiencial de múltiples pantallas independientes, que recurre al concepto del espectador emancipado de Jacques Rancière. Las reacciones de los visitantes demuestran que las estrategias para una exposición no lineal y abierta, usadas para presentar los medios audiovisuales y los objetos, efectivamente aumentan el interés y evocan perspectivas múltiples. Además, al retener información factual, se invita a los visitantes a participar en una búsqueda personal de conexiones, a veces con la ayuda de otros. Situado en un ambiente íntimo, donde cada persona es libre de seguir su propia ruta y con acceso directo a las fuentes originales, los visitantes toman el papel de intérpretes dentro de la obra.

\section{INDEX}

Palabras claves: cine expandido, instalación, inmersivo, experiencia de visitante, performance, patrimonio cultural colonial, Índias Orientales Neerlandesas, Política de la memoria

Keywords: expanded cinema, installation, immersive, visitor experience, performance, colonial cultural heritage, Dutch East Indies, memory politics.

Mots-clés: cinéma élargi, immersion, expérience du visiteur, performance, héritage culturel colonial, les Indes occidentales néerlandaises, politiques de la mémoire

\section{AUTHOR}

\section{JANINE PRINS}

Visiting lecturer Leiden University janineprins@xs4all.nl

Janine Prins is an independent visual anthropologist and documentary filmmaker affiliated with the Visual Ethnography programme at Leiden University. Her main research interests lie in the exploration of new combinations of audiovisual media in relation to social science topics, be it through the use of television, cinema, new media, design thinking or most recently: installation art practices. As a research fellow for Waag Society, she participated in RICHES, a project on $21^{\text {st }}$ century cultural heritage, in collaboration with the Dutch National Museum of Ethnology. 